\title{
METAPHORIC NETWORKS IN THE ENGLISH TRANSLATIONS OF IMANTS ZIEDONIS'S COLORFUL TALES
}

\author{
ELITA SALIN̦A \\ Latvian Academy of Culture, Latvia
}

\begin{abstract}
The present paper analyzes the English translations of Imants Ziedonis's Krāsainas pasakas (Colorful Tales) from the perspective of intercultural translation studies, paying special attention to the translational choices made to transfer individual elements of the color-based metaphoric networks. It concludes that a very high level of biculturalisation is required to align these densely figurative texts with the cognitive environment of the target audience, and a systematic approach is called for to preserve the stylistic and conceptual integrity of the metaphoric networks.
\end{abstract}

Key words: Imants Ziedonis's Colorful Tales, intercultural translation studies, figurative meanings of colors, metaphoric networks, cultural filtering

\section{INTRODUCTION}

Like many other minor European cultures, Latvian culture has been a recipient, rather than a source, of translations. Occurrences of the translations of Latvian literature into English have been random and have seldom elicited wider interest in the source culture, often being seen as peripheral or marginal events. The years 2016-2018, however, may mark a shift, if not in the numbers of translations, then in the approach to introducing contemporary Latvian authors to the world. In April 2018, Latvia alongside with the other Baltic Countries was a market focus country of the London Book Fair to honor the centenary of Latvian statehood. These events have heightened awareness of the relevance of translations as a means of representing Latvian culture abroad and also activated the need to assess and research the strategies employed in the translations of Latvian literature.

Among these recent translations, one in particular offers the Englishreading public an insight into the Latvian literature of the Soviet era. It is the first complete English translation of Imants Ziedonis's Colorful Tales, published in 2017, 44 years after the first edition of this collection of fairy tales. It is possible to name numerous reasons why this popular work by one of the most widely 
translated modern Latvian authors had to wait so long for its first complete English version. Apart from the political circumstances, a major factor might have been the sheer difficulty of translating these densely allusive and multilayered texts. Furthermore, the time lag has added one more complication for translators; the radical political and social changes caused by the collapse of the Soviet Union have virtually obliterated the implied criticism of the bleakness and shallowness of the stagnation-era Soviet reality, modifying its status in the source culture. Translator Ieva Lešinska believes that 'Nowadays it is a completely different work. Much more childish. It is impossible to recreate the 1970s and the way we read Ziedonis then' (Adamaite, 2017; trans. mine).

Consequently, the present paper has two major objectives: 1) to analyze the translational choices made to transfer the individual elements of the colorbased metaphoric networks that vary from fairy-tale to fairy-tale, paying special attention to cases when the figurative meanings ascribed to colors in Latvian and Anglo-American cultures do not overlap or overlap partially; 2) to view these translational choices as indications of higher-order pragmatic strategies that the translators have applied to convey the universe of discourse or the subject matter of the source text (Lefevere, 1992: 87).

The primary material analyzed is Ieva Lešinska's 2017 translation of Colorful Tales supplemented by the alternative translations of selected fairy tales undertaken by the American-Latvian translator and linguist Bitite Vinklere and the Canadian writer and poet Barry Callaghan.

\section{FIGURATIVE MEANINGS OF COLORS AS A TRANSLATION PROBLEM}

Colors are an integral part of our experience of bodily-being-in-the world and sensory perceptions. Cognitive scientist Don Dedrick notes that explanations of color categorization can operate with four dimensions: biological states related to the brain, psychological states related to the mind, linguistic behavior or language, and, finally, socially transmitted information derived from culture (Dedrick, 2015: 274). Translation studies and practice have been primarily concerned with the last two dimensions and not only due to the fact that crosslinguistically color terms may represent the same color categories but different stylistic registers. A major factor has been the culture-specific nature of colorbased figurative meanings. Metaphor scholar Richard Trim admits that it is difficult to establish 'universal trends in colour metaphors', as 'evidence for cultural differences abound', although 'within European languages there are more correspondences due to a common cultural heritage' (Trim, 2007: 57, 59).

Thus, translational choices made to transfer color-based phraseological units and metaphors can be most fruitfully viewed from the perspective of intercultural translation studies, since translators often have to deal with more than semantic difficulties. Symbolization of colors often entails culture-bound 
notions and allusions pointing to what Andrè Lefevere famously designated the real untranslatable, which does not reside in syntactic transfers of semantic constructions, but rather in the particular way in which cultures all develop their own "shorthand"' (Lefevere, 1992: 56).

In literary works, this intercultural untranslatability may be compounded by the fact that writers include color terms in their own individual patterns of figurative meanings that are developed throughout the text and presuppose the necessity to treat them as part of discourse, not as separate and isolated tropes. Paul Ricoeur argues in favor of a more holistic perception (and by implication translation) of metaphors, which draws on the theory of models in scientific language and argumentation:

[...] what on the poetic side corresponds exactly to the model is not precisely what we have called the "metaphorical statement," that is, a short bit of discourse reduced most often to a sentence. Rather, as the model consists in a complex network of statements, its exact analogue would be the extended metaphor - tale, allegory. What Toulmin calls the "systematic deployability" of the model finds its equivalent in a metaphoric network and not in an isolated metaphor. (Ricoeur, 2003: 287-288)

It is precisely this systematic use or networking of metaphors that carries the referential function enabling poets and creative writers in general to project a world (Ricoeur, 2003: 288). Hence, the further analysis of the English translations of Ziedonis's fairy tales will consider patterns of figurative meanings established not only through metaphors 'proper', but also other tropes and phraseological units in interaction with phonetic and syntactic stylistic devices and non-figurative elements, especially culture-specific items.

\section{CULTURE-SPECIFIC MEANINGS OF COLOR WHITE IN THE WHITE FAIRY TALE}

The collection of the fairy tales opens with The White Fairy Tale (Baltā pasaka) describing a day when the first snow covers the world and obliterates all the familiar colours. White may seem a paradoxical choice for introducing a series of colourful tales, as it may denote both the absence and presence of color. However, it also indicates the blurring of the boundaries between reality and imagination out of which the rest of the fairy tales grow.

The focal point of the metaphoric network in The White Fairy Tale is the phraseological unit baltā diena (the white day) that draws together various denotative meanings of the color white in Latvian. In the source text, it can be interpreted as a day which is white, because it has snowed, also that period of the day when it is fully light (alternative to the English in broad daylight); furthermore, the description of what happens on this white day implies that it is a happy and careless day. Everyday objects such as ink and shoe polish turn white 
and 'We eat only white bread and drink white coffee' (Ziedonis, 2017: 7), namely, wheat bread not rye bread and coffee with cream and milk that lacks bitterness.

All these particular instances of the use of the color white point to a subtype of the conceptual metaphor GOOD IS LIGHT, namely, GOOD IS WHITE, that is prominent in the Latvian cognitive environment. In Latvian folk songs dainas, the color white denotes purity, virtue, industry, emotional attachment to a person or an object, etc. It is extremely difficult to convey this complexity of the perception of white to the English-language readership, as it does not exist in the target culture.

In the two published English translations of this fairy tale, radically different strategies have been adopted. Lešinska has resorted to literal translation. Thus, the sentence 'Visi koki - balti, eju pa mežu nevaru saprast, kur koks, kur baltã diena' (Ziedonis, 2016: 10) has been rendered as 'All the trees are white: I walk through the forest and can't distinguish between white trees and the white day' (Ziedonis, 2017: 7). Callaghan, who translated Ziedonis's works through the medium of interlinear translations, however, introduces a compensatory metaphor of a snowstorm of whiteness 'A blizzard of trees - a white tree lost in a white day in the woods' preceded by another compensatory device, the pun 'Now the world is white. So white it's a whiteout' (Ziedonis, 1990: 115). The context actualizes the link between whiteout and its counterpart blackout, emphasizing the paradox that excess of light and whiteness blinds.

Both translations partially transmit the qualities of the original universe of discourse, yet Lešinska's version emphasizes more the pristine white cover of snow, while the earlier translation by Callaghan creatively develops the theme of the confusion of senses.

\section{CULTURAL FILTERING IN THE BLUE FAIRY TALE}

Another instance of incomplete overlapping of the figurative meanings of colors can be observed in The Blue Fairy Tale (Zila pasaka). Here it is possible to draw a comparison between Ieva Lešinska's translation and an earlier translation done by Bitite Vinklere. The fairy tale recounts how horses from the whole world come together and feeling endangered in a world being taken over by cars decide to create an eternal blue horse of hope.

The association between hope, sadness and the color blue is widespread among Western cultures and should be easily recognizable to the Englishlanguage readership. There is, however, a nuance of usage which can be easily overlooked by translators. In fact, there are no phraseological units in Latvian that would directly link the color blue with sadness. The link is established rather through such stable collocations as zils mijkrēslis (blue twilight), zils novakars (blue evening), or zilas tāles (blue distance), which, unless revitalized by original contexts, are perceived as poetical clichés and indicate romantic longings and melancholy due to unfulfilled desires and dreams. Consequently, according to 
Latvian color symbolization, blue does not refer to everyday depression and sadness.

In view of this, it is significant that Vinklere has attempted to disrupt the routine association between the color blue and sadness, while Lešinska has used a well-established English phraseological unit. The sentence 'Tad noskuma zilais zirgs, bet visi zirgi teica, ka arī skumjas ir zilas un labi viñam piestāv, un savu lēmumu vairs nemainija' (Ziedonis, 2016: 26) has been translated respectively as 'The blue horse grew sad, but the other horses said sadness was blue and suited him' (Ziedonis, 2008: 127) and 'This made the blue horse become sad, but all the other horses said that sadness was the same as having "the blues" and therefore sadness suited him, so they did not change their decision' (Ziedonis, 2017: 20, in all the quotations emphasis mine). It seems that the 2017 translation of The Blue Fairy Tale generally seeks greater accommodation with the target culture, even if it sometimes contradicts the overall symbolism of the source text as can be seen from the following example.

Stylistically one of the most noticeable features of The Blue Fairy Tale is persistent alliteration. Since the words zirgs (horse) and zils (blue) both begin with the same letter, the alliterating consonant in the source text is $[\mathrm{z}]$, which in the English translations has been substituted with alliteration based on the consonant $[\mathrm{b}]$. Although neither of the English versions preserves the sequence of the three strong stressed syllables of the original opening sentence 'Zils zirgs zirnos' (Ziedonis, 2016: 26), they contain alternative sound patterns: 'A blue horse in a field of bluebells' (Ziedonis, 2008: 127) and 'A blue bronco amid blossoms' (Ziedonis, 2017: 19). It can be observed that the second translation is terser and bears stronger phonological resemblance to the source text; however, the use of the hyponym bronco instead of the generic term horse causes a shift in meaning and identifies the Blue Horse of Hope with the unbroken, wild horses of western North America. As the Blue Horse of Hope is akin to Pegasus, the winged horse of inspiration, although he does not represent poetic elation but rather nostalgia for the past and poetic melancholy necessary for artistic creation, this association with the Wild West seems a foreign element, especially taking into account the fact that all the animals and plants mentioned in the fairy tales are indigenous to Latvia.

The above examples raise the issue of the pragmatic strategies that, according to Andrew Chesterman, often reflect 'a translator's global decisions concerning the appropriate way to translate the text as a whole' (Chesterman, 2016: 104). Especially relevant in this case is the application of cultural filtering or 'the way in which SL [source language] items, particularly, culture specific-items, are translated as TL [target language] cultural and functional equivalents, so that they conform to TL norms' (Chesterman, 2016: 104, insertion mine). In the 2017 translation cultural filtering can be traced also in some of the compensatory stylistic devices without due consideration of the stylistic and conceptual integrity of this particular metaphoric network. 


\section{PHRASEOLOGICAL PUNS IN THE PURPLE FAIRY TALE}

Application of cultural filtering comes to the foreground also in the translation of Lilla pasaka (The Purple Fairy Tale). First of all, the original color term cannot be precisely rendered into English because the Germanism lilla in Latvian has sarcastic connotations. Moreover, the text contains an extended pun on the use of this word as the color category bluish red and its colloquial meaning drunk, which does not appear in the text of the fairy tale but clearly summarises the central idea of the story of a drunkard whose purple nose literally produces color purple and later in a plot twist reminiscent of Nikolay Gogol's satirical story The Nose deserts him.

A recurrent feature of this metaphoric network is phraseological puns or 'an instantial pattern where two interpretations can be assigned to the case of use: direct and figurative. The salient feature of this pattern is the juxtaposition and contradistinction of the figurative meaning of the PU [phraseological unit] and the literal meaning of a component or components' (Naciscione, 2001: 236, insertion mine). Thus, the main character's head literally starts spinning as soon as he has had a drink. This phraseological pun is used as a plot element and the fairy tale contains a number of tropes extending this concept. Among them is another subordinate phraseological pun ùdens galva (water head) that acquires double contextual meaning a stupid person and a teetotaller contrasted with the nonce-formation šnabja galva (booze head) in the drunkard's boast that booze gives him knowledge: 'Mana galva nav nekāda muļ, ka galva. Mana galva nav ūdens galva, bet šñabja galva. Viņa pati zina, kā griezties un kā apstāties' (Ziedonis, 2016: 44). Lešinska has avoided the pejorative designation water head by introducing into her translation the medical term hydrocephalus and then creating a pseudo-medical term vodkacephalus combined with the explication booze head: 'My head is no fool's head. My head is no hydrocephalus. My head is a booze head, a vodkacephalus. It knows how to spin and how to stop' (Ziedonis, 2017: 34). It should be noted that the translator has created an additional etymological pun, since vodka (booze) in Russian shares the same root with voda (water). Inventive and original as these translations are, they do not fit very well with the background of the main character, an ordinary worker at a collective farm who is unlikely to use sophisticated vocabulary.

\section{CONCLUSION}

Even this brief discussion of translational choices from the existent English translations of Ziedonis's Colorful Tales indicates that they possess a high degree of untranslatability owing to the complexity of the metaphoric networks established by the poet and their culture-specific nature. In literary texts that are to such a high extent reliant on the interplay of the literal and figurative meanings and culture-bound subtexts as Ziedonis's fairy tales, a very high level of biculturalisation is required to align them with the cognitive environment of the target 
audience. The dilemma faced by translators is that attempts to smooth intercultural communication and adapt these texts to the background knowledge of the target-language readership, especially if the target language is so global and globalizing as English, may lead to a stylistic flattening of the texts, while gross insensitivity to filling in the gaps of the target-language readership may render them incomprehensible. Translating Ziedonis's fairy tales seems to call for a systemic approach that maps the functions of individual expressive means and stylistic devices in discourse and takes into account the interaction between various levels of text organization in order to preserve the stylistic and conceptual integrity of the color-based metaphoric networks.

\section{REFERENCES}

Adamaite, U. (2017) Intervija ar tulkotāju Ievu Lešinsku. Tagad kurmis ir vienkārši kurmis [Interview with translator Ieva Lešinska. Now a Mole is just a Mole]. In Kultūras Diena. Available from https://www.diena.lv/raksts/kd/intervijas/intervija-ar-tulkotaju-ievulesinsku.-tagad-kurmis-ir-vienkarsi-kurmis-14182724 [Accessed on 1 May 2019].

Chesterman, A. (2016) Memes of Translation: The Spread of Ideas in Translation Theory. Amsterdam: John Benjamins.

Dedrick, D. (2015) Colour language, thought, and culture. In F. Sharifian (ed.) The Routledge Handbook of Language and Culture (pp. 270-293). London: Routledge.

Lefevere, A. (1992) Translation, Rewriting and Literary Fame. London: Routledge.

Naciscione, A. (2001) Phraseological Units in Discourse: Towards Applied Stylistics. Riga: Latvian Academy of Culture.

Ricoeur, P. (2003) The Rule of Metaphor: The Creation of Meaning in Language (trans. R. Czerny et al.). London: Routledge.

Trim, R. (2007) Metaphor Networks: The Comparative Evaluation of Figurative Language. London: Palgrave Macmillan.

\section{SOURCES ANALYZED}

Ziedonis, I. (1990) Flowers of Ice (trans. B. Callaghan). Riverdale-on-Hudson, New York: Sheep Meadow Press.

Ziedonis, I. (2008) The Blue Fairy Tale (pp. 127-128, trans. B. Vinklere). In Fairy Tale Review. The White Issue No 4. Alabama: The University of Alabama Press.

Ziedonis, I. (2016) Krāsainas pasakas. Rīga: Zvaigzne ABC.

Ziedonis, I. (2017) Colorful Tales (trans. I. Lešinska). Rìga: Jumava.

Elita Salina (Dr. Philol., Assoc. Prof.) is currently working at the Latvian Academy of Culture. Her research interests include British literature, poetry studies, literary translation.Email: elita.salina@gmail.com 